UDK 641.5:665.12 (497.11)

Original research paper

\title{
TRADITIONAL FOOD IN SERBIA: SOURCES, RECIPES AND FATTY ACIDS PROFILES
}

\author{
Tamara B. Popović*, Aleksandra Č. Arsić, Jasmina D. Debeljak Martačić, \\ Gordana P. Petrović Oggiano, Mirjana A. Gurinović, Vesna M. Vučić, Marija D. Glibetić \\ University of Belgrade, Institute for Medical Research, Dr Subotića 4, 11129 Belgrade, Serbia
}

\author{
*Corresponding author: \\ Phone: +381113031997 \\ Fax +381 112030169 \\ E-mail address: poptam@gmail.com
}

\begin{abstract}
Traditional foods play a major role in traditions of different cultures and regions for thousands of years while preparation methods of traditional foods are part of the folklore of a country or a region.

This paper presents recipes and fatty acid profiles of selected commonly consumed traditional foods in Serbia. The obtained fatty acid composition data are used for making conclusions about meals which are commonly consumed in Serbia. Traditional Serbian dairy products, cheese and kajmak, contained $70 \%$ SFAs (mostly palmitic acid). Commonly used meal in Serbian cuisine, prebranac, also contained palmitic acid and oleic acid (38.67\% and $35.58 \%$ respectively), while linoleic acid was presented with $17.34 \%$, similarly to vanilice. Ajvar, frequently used as a salad, is rich in linoleic acid (49.12\%) but less rich in palmitic acid. Trans fatty acids were found in very small amounts in all foods.
\end{abstract}

Keywords: traditional food, fatty acids composition

\section{INTRODUCTION}

Most people can name at least one traditional food of the region they come from. The internet search for "traditional food" shows that numerous collections of traditional food recipes are available worldwide.

Traditional food is a food with a specific feature or features which distinguish it clearly from other similar products of the same category in terms of the use of "traditional ingredients" (raw material of primary products) or "traditional composition" or "traditional type of production and /or processing method" (Costa, 2005).

Traditional foods have been influenced by many factors, such as the availability of raw materials and therefore in countries without the access to the sea the availability of fish and seafood is usually lower than in countries with a large coastal area (Davis, 2005). Moreover, traditional foods and dishes have been influenced by religious habits (Parasecoli, 2005).

Average daily energy requirements are significantly lower than in past centuries (Trichopoulou et al., 2006). Although developed a long time ago, numerous traditional foods, have place in healthy diet today. Some of them may not meet nowadays nutritional needs, because they are energy dense food or possess a high fat content. It makes sense to modify the nutrient composition of some traditional foods to make them more appropriate for the nutritional needs in the $21^{\text {st }}$ century.

The aims of our study were: 1) to present a recipes of Serbian traditional food 2) to determine fatty acid composition of tradi- 
tional food 3) to discuss health effects of Serbian traditional food in relation to obtained results.

\section{MATERIALS AND METHODS}

Some of commonly consumed Serbian traditional foods was identified as follows: gibanica (filo pastry with cheese fill), prebranac (first cooked, than baked beans), ajvar (cooked pepper and eggplant spread), fresh cheese, kajmak (creamy dairy product), and vanilice (cookies).

Fresh cheese, kajmak and ajvar were purchased from three different producers, $100 \mathrm{~g}$ of each were pooled and $200 \mathrm{~g}$ of representative sample was taken for further analysis. Gibanica, vanilice and prebranac were prepared using the most common recipes given bellow. Sunflower oil was replaced with flaxseed oil or some other oil rich in omega-3 (n-3) fatty acids.

Ajvar is a mixture of roasted sweet pepper and eggplant, which could be mashed or left chunky, and served as a relish or spread.

Prebranac was prepared from cooked beans, stewed leek and onions, with the addition of ground red paprika powder, salt and pepper. Combined ingredients were baked in oven for $30 \mathrm{~min}$.

Kajmak should be made by boiling unpasteurized, unhomogenized (raw) cow or sheep milk and skimming off the cream that rises on the top. If left to ferment and ripen, aged kajmak has a stronger taste and is yellow in color.

Serbian cheese is usually made from unpasteurized cow's milk. The formed young curd is pressed into flat disc, then the cheese is left to dry on the open air. The surface is rubbed and salted several times over next few days and finally, product is stored in wooden container in brine. The taste of the cheese is slightly sour and salty.

Gibanica is made of sheets of phyllo, eggs, oil, cheese, kajmak, sparkling water and milk. Mixture of ingredients should be placed over the sheet of phyllo in layers and baked in the oven until golden brown.
Vanilice are traditional cookies usually prepared from a dough obtained by mixing pork fat, eggs, flour, salt, ground wallnuts ang vinegar. Form a dough into a $1 \mathrm{~cm}$ thick layer, cut out the cookies in a round shape and bake them at $180{ }^{\circ} \mathrm{C}$ for 15 minutes. The obtained cookies should be filled with apricot jam and combined to form a sandwich-like shape followed by coating in sugar.

\section{Analysis of fatty acids in traditional food}

Fat was extracted according to method of Folche et al. (1957). Ten milligrams of Serbian cheese, kajmak, gibanica, vanilice, prebranac and ajvar, and $2.5 \mathrm{~mL}$ of chloroform, $1.25 \mathrm{~mL}$ of methanol with BHT (butylated hydroxytoluene) were mixed and homogenized. Chloroform (3.75 mL), methanol $(5 \mathrm{~mL})$ and water $(0.45 \mathrm{~mL})$ were added in samples which were left overnight in the freezer. Obtained lipid extracts were filtered and evaporated to dryness. Lipid dry residues were dissolved in $2 \mathrm{~mL}$ of chloroform-methanol $(1: 1, \mathrm{v} / \mathrm{v})$ and transferred to test tubes for methyltion by adding $0.2 \mathrm{~mL}$ of $2 \mathrm{M} \mathrm{NaOH}$ in methanol and $1.5 \mathrm{~mL}$ of hexane into $0.2 \mathrm{~mL}$ lipid extracts and heated at $85{ }^{\circ} \mathrm{C}$ for 1 hour. Addition of $0.2 \mathrm{~mL}$ of $1 \mathrm{M} \mathrm{H}_{2} \mathrm{SO}_{4}$ in methanol and heating 2 hours at $85^{\circ} \mathrm{C}$ finished methylation. Cooled tubes were centrifuged for $15 \mathrm{~min}$, and the hexane layer was transferred into a clear vial.

\section{GCanalysis}

Separations of the methyl esters were carried out using a gas chromatograph (Shimadzu 2014; Kyoto, Japan), equipped with a split/splitless injector and a flame ionization detector. The methyl ester separation was carried out on capillary column RESTEK RTX 2330 (60 m, 0.25 mm i.d., $0.20 \mu \mathrm{m}$ df; RESTEK US, Bellefonte, PA) using helium as the carrier gas. The injector and detector temperature was set at $220{ }^{\circ} \mathrm{C}$ and $260{ }^{\circ} \mathrm{C}$, respectively. The injecttion was performed in split mode with 1:100 split-ratios. The temperature of the column was initially set at $140{ }^{\circ} \mathrm{C}$ for 5 min, and then increased to $210^{\circ} \mathrm{C}$ at the rate of $3{ }^{\circ} \mathrm{C} / \mathrm{min}$, and held at this temperature for $20 \mathrm{~min}$. Each fatty acid (FA) was identified with reference to the retention 
time of that FA in standard PUFA-2 (Sigma-Aldrich, St. Louis, MO). The content of FA was expressed as percentage of total FAs.

\section{RESULTS AND DISCUSSION}

The results of fatty acid composition, total saturated (SFA), monounsaturated (MUFA) and polyunsaturated (PUFA) fatty acids of traditional foods in Serbia are shown in Table 1. T

The commonly consumed cow cheese consists of about $70 \%$ of SFAs, and among them the most abundant are palmitic $(36.57 \%)$, miristic $(12.69 \%)$ and stearic $(8.73 \%)$. In addition, cow cheese has high content of oleic acid (22.18\%), while other FAs including 18:1, trans is present in a small percentage. Similar FAs composition was found in kajmak (Table 1).
Unlike Serbian cheese and kajmak, gibanica contained high percentage of oleic acid (31.94\%), slightly lower percentage of palmitic (25.54\%) and linoleic acid $(13.08 \%)$. The content of the most atherogenic, myristic acid, in gibanica was $7.37 \%$, while the content of stearic acid was similar as in cheese and kajmak.

Trans FAs were not detected in gibanica, while the other of FAs were present in less than $2 \%$. Oleic and palmitic acid were found to be the most abundant in vanilice (26.54\% and $23.17 \%$ respectively), whereas linoleic acid was present with $13.51 \%$. Most abundant FAs in prebranac were palmitic and oleic acid $(38.67 \%$ and $35.58 \%$ respectively), while linoleic acid was present with $17.34 \%$. Other FAs were present in low amounts. On the other hand, ajvar was rich in linoleic (49.12\%), oleic $(25.51 \%)$ and palmitic acid $(15.68 \%)$.

Table 1.

Fatty acids composition (\%,w/w) of traditional foods in Serbia

\begin{tabular}{|c|c|c|c|c|c|c|}
\hline Fatty acid & Cheese & Kajmak & Gibanica & Vanilice & Prebranac & Ajvar \\
\hline $4: 0$ & $0.37 \pm 0.02$ & $0.92 \pm 0.05$ & $2.46 \pm 0.08$ & N.D. & N.D. & N.D. \\
\hline $6: 0$ & $1.19 \pm 0.02$ & $1.28 \pm 0.13$ & $1.41 \pm 0.20$ & N.D. & N.D. & N.D. \\
\hline 8:0 & $1.20 \pm 0.04$ & $1.15 \pm 0.05$ & $1.05 \pm 0.14$ & N.D. & N.D. & N.D. \\
\hline $10: 0$ & $2.80 \pm 0.08$ & $2.74 \pm 0.06$ & $1.82 \pm 0.07$ & $0.06 \pm 0.01$ & & $0.45 \pm 0.03$ \\
\hline $12: 0$ & $3.50 \pm 0.07$ & $3.50 \pm 0.07$ & $1.77 \pm 0.10$ & $0.03 \pm 0.01$ & $0.27 \pm 0.03$ & $0.70 \pm 0.04$ \\
\hline $14: 0$ & $12.65 \pm 0.29$ & $12.52 \pm 0.18$ & $7.45 \pm 0.08$ & $0.15 \pm 0.03$ & $1.01 \pm 0.04$ & $3.22 \pm 0.04$ \\
\hline $14: 1$ & $1.22 \pm 0.03$ & $1.23 \pm 0.02$ & $0.80 \pm 0.06$ & N.D. & N.D. & N.D. \\
\hline $15: 0$ & $1.33 \pm 0.04$ & $1.33 \pm 0.03$ & $0.54 \pm 0.05$ & N.D. & N.D. & N.D. \\
\hline $15: 1$ & $0.41 \pm 0.03$ & $0.43 \pm 0.01$ & $0.18 \pm 0.03$ & N.D. & N.D. & N.D. \\
\hline $16: 0$ & $36.70 \pm 0.16$ & $36.69 \pm 0.12$ & $25.53 \pm 0.06$ & $7.74 \pm 0.11$ & $38.77 \pm 0.11$ & $15.63 \pm 0.18$ \\
\hline $16: 1, n-7$ & $1.84 \pm 0.05$ & $1.79 \pm 0.04$ & $1.60 \pm 0.08$ & $0.13 \pm 0.02$ & $0.16 \pm 0.08$ & N.D. \\
\hline $17: 0$ & $0.71 \pm 0.03$ & $0.73 \pm 0.03$ & $0.49 \pm 0.04$ & N.D. & $0.07 \pm 0.01$ & N.D. \\
\hline $17: 1$ & $0.36 \pm 0.03$ & $0.33 \pm 0.04$ & $0.28 \pm 0.05$ & N.D. & $0.10 \pm 0.02$ & N.D. \\
\hline $18: 0$ & $8.81 \pm 0.07$ & $8.73 \pm 0.09$ & $8.81 \pm 0.07$ & $2.76 \pm 0.09$ & $3.61 \pm 0.07$ & $5.17 \pm 0.08$ \\
\hline 18:1 trans & $1.48 \pm 0.04$ & $1.52 \pm 0.10$ & $1.04 \pm 0.90$ & N.D. & $0.62 \pm 0.05$ & N.D. \\
\hline $18: 1, n-9$ & $22.16 \pm 0.08$ & $21.85 \pm 0.48$ & $31.15 \pm 0.81$ & $27.58 \pm 0.34$ & $35.55 \pm 0.09$ & $25.48 \pm 0.04$ \\
\hline $18: 1, n-7$ & $0.42 \pm 0.02$ & $0.43 \pm 0.01$ & N.D. & $0.62 \pm 0.04$ & $2.09 \pm 0.04$ & N.D. \\
\hline $18: 2, n-6$ & $1.60 \pm 0.07$ & $1.58 \pm 0.04$ & $12.73 \pm 0.46$ & $58.03 \pm 0.36$ & $17.37 \pm 0.10$ & $49.35 \pm 0.29$ \\
\hline $18: 3, n-6$ & $0.17 \pm 0.01$ & $0.19 \pm 0.04$ & $0.13 \pm 0.03$ & $0.21 \pm 0.02$ & N.D. & N.D. \\
\hline $18: 3, n-3$ & $0.45 \pm 0.04$ & $0.44 \pm 0.04$ & $0.44 \pm 0.03$ & $2.69 \pm 0.13$ & N.D. & N.D. \\
\hline $20: 0$ & $0.63 \pm 0.02$ & $0.61 \pm 0.04$ & $0.32 \pm 0.04$ & N.D. & $0.36 \pm 0.03$ & N.D. \\
\hline SFA & $69.88 \pm 0.12$ & $70.21 \pm 0.41$ & $51.65 \pm 0.06$ & $10.75 \pm 0.15$ & $44.10 \pm 0.02$ & $25.18 \pm 0.25$ \\
\hline MUFA & $26.42 \pm 0.18$ & $26.06 \pm 0.53$ & $34.02 \pm 0.74$ & $28.32 \pm 0.34$ & $37.91 \pm 0.05$ & $25.48 \pm 0.04$ \\
\hline PUFA & $2.22 \pm 0.07$ & $2.21 \pm 0.06$ & $13.30 \pm 0.43$ & $60.93 \pm 0.49$ & $17.37 \pm 0.10$ & $49.35 \pm 0.29$ \\
\hline$n-6$ & $1.77 \pm 0.09$ & $1.77 \pm 0.08$ & $12.86 \pm 0.44$ & $58.23 \pm 0.38$ & $17.37 \pm 0.10$ & $49.35 \pm 0.29$ \\
\hline$n-3$ & $0.45 \pm 0.04$ & $0.44 \pm 0.04$ & $0.44 \pm 0.03$ & $2.69 \pm 0.13$ & N.D. & N.D. \\
\hline n6/n3 & $3.98 \pm 0.49$ & $4.02 \pm 0.55$ & $29.61 \pm 2.82$ & $21.67 \pm 0.95$ & N.D. & N.D. \\
\hline
\end{tabular}

N.D.- not detected; Results are presented as percentage (average $\pm S D$ ) of fatty acids of total lipids; SFA-saturated fatty acids; MUFA-monounsaturated fatty acids; PUFA-polyunsaturated fatty acids 
Among the other traditional food, Serbian cheese and kajmak are daily consumed. While cow's milk cheese and kajmak in general are perceived as healthy foods due to their content of protein, minerals and vitamins (Popović et al., 2011), their fat contains about $70 \%$ of SFAs among which the most abundant are myristic and palmitic acids. Both myristic and palmitic acids are dietary constituents that powerfully raise serum total cholesterol and LDL-cholesterol levels in humans, increasing the risk of cardiovascular diseases. Beside the SFAs, in Serbian cheese and kajmak there were around $20 \%$ of MUFAs, primarily oleic acid. Oleic acid has a beneficial effect on cardio-vascular diseases and skin repair, while some studies also suggest its beneficial effect on cancer, autoimmune diseases and inflammation (Sales-Campos et al., 2013). Intakes of SFAs in many countries, including Serbia, are higher than the recommended levels (Hulshov et al., 1999). Substitution of dietary saturated fats with monounsaturated ones may reduce coronary heart disease risk, mainly via LDL-cholesterol reduction (Kris-Etherton et al., 1999; Warhburg, 2004; Vessby, 2001). Thus, we recommend a lower intake of cheese and kajmak and increased intake of olive oil. Also, the food technology, which modifies the FAs profile of foods naturally rich in SFAs in favors of oleic acid, is recommended to be used. The predominant FAs in gibanica were SFAs, similar to cheese and kajmak, but the content of MUFAs was higher. Dominant FAs in prebranac were palmitic and oleic acid. High intake of palmitic acid contributes to the development of cardio-vascular diseases (Haug et al., 2007). Ajvar mostly contained linoleic and oleic acids. Mammals are unable to synthesize linoleic acid, which is a precursor of omega-6 (n-6) FAs, thus it must be provided by food intake. In the last 50 years, the consumption of n-6 FAs has substantially increased, whereas the intake of omega-3 (n-3) FAs has decreased (Simopoulos et al., 1999). Increased consumption of food with high $n-6$ PUFAs content increases $n-6 / n-3$ ratio, which leads to thrombosis and inflammatory reactions. Opposite, high n-3/n-6 ratio has cardio protective, antithrombotic and anti-inflammatory properties (Lenas et al., 2011).

According to Trichopoulou et al. (2007), dietary patterns are influenced by the local availability of foods and the cultural and socioeconomic environment, but there is a trend for transfer and assimilation of new habits between countries. In the 1960's, the diet of Mediterranean populations was characterized by a high consumption of fruits and vegetables, contrary to the low consumption of these foods in northern European countries. These differences seem to be diminishing. Contemporary patterns reveal that the Mediterranean population is straying from their traditional dietary choices, whereas Mediterraneanstyle eating gains popularity in northern European countries (Trichopoulou et al., 2006).

\section{CONCLUSION}

Commonly consumed traditional food in Serbia is rich in SFAs, mostly palmitic and mirystic acids, which are known as atherogenic. On the other hand, high content of oleic acid, known as anti-inflammatory and anti-tumor, was found in gibanica, while high content of linoleic acid was found in ajvar.

\section{ACKNOWLEDGEMENTS}

This paper is result of the research on the Project III41030 financed by Ministry of Education, Science and Technological Development of Republic of Serbia and was performed on behalf of the European Food Information Resource (EuroFIR) Consortium and funded under the EU FP6 "Food Quality and Safety Programme", Project contract no. FP6-513944, www.eurofir.net

\section{REFERENCES}

1. Costa, A.P. (2005). Portugal. A dialogue of cultures. In: Culinary cultures of Europe. Identity, diversity and dialogue (C. Goldstein and K. Merkle, eds). Council of Europe Publishing, Verlagsgruppe Lübbe, Germany, pp 347-356.

2. Davis, T. (2005). Preface. In: Culinary cultures of Europe. Identity, diversity and dialogue (C. Goldstein and K. Merkle, eds). Council of Europe Publishing, Verlagsgruppe Lübbe, Germany, pp 9.

3. Folch J., Lees M., Sloane G.H. (1957). A simple method for the isolation and purification of total 
lipids from animal tissues. The Journal of Biological Chemistry, 226, 497-509.

4. Haug A., Hostmark A.T., Harstad O.M. (2007). Bovine milk in human nutrition - a review. Lipids in Health and Disease, 6, 25-41.

5. Hulshof K., van Erp-Baart M.A., Anttolainen M., Becker W., Church S.M., Couet C. (1999). Intake of fatty acids in Western Europe with emphasis on trans fatty acids: the TRANSFAIR study. European Journal of Clinical Nutrition, 53, 143-57.

6. Kris-Etherton P.M. (1999). Monounsaturated fatty acids and risk of cardiovascular disease. Circulation, 100, 1253-1258.

7. Lenas D., Papadimitrou E., Bitchava C., Nathanailides C. (2011). Fatty acid content and potential health benefits of consuming gilthead sea bream (Sparus aurata) and sea bass (Dicentrarhus labrax). Acta Alimentaria, 40, 1, 45-51.

8. Misirli G., Benetou V., Lagiou P., Bamia C., Trichopoulos D., Trichopoulou A. (2012). Relation of the traditional Mediterranean diet to cerebrovascular disease in a Mediterranean population. American Journal of Epidemiology, 176 (12), 1185-1192.

9. Parasecoli F. (2005). Introduction. In: Culinary cultures of Europe. Identity, diversity and dialogue (C. Goldstein and K. Merkle, eds). Council of Europe Publishing, Verlagsgruppe Lübbe, Germany, pp 11-37.

10. Popović T., Debeljak-Martacić J., Tepsić J., Kujundzić S., Konic-Ristić A., Glibetić M., Gurinović M. (2011). Analytical analysis of tra- ditional foods: filling the gap in Serbian food composition database information. Food and Feed Research, 38 (1), 39-42.

11. Sales-Campos H., Souza P.R., Peghini B.C., da Silva J.S., Cardoso C.R. (2013). An overview of the modulatory effects of oleic acid in health and disease. Mini-Review in Medical Chemistry, 13 (2), 201-210.

12. Simopoulos A.P. (1999). Essential fatty acids in health and chronic disease. American Journal of Clinical Nutrition, 70, 560S -569S.

13. Trichopoulou A., Vasilopoulou E., Georga K., Soukara S., Dilis V. (2006). Traditional foods: Why and how to sustain them. Trends in Food Science \&Technology, 17, 498-504.

14. Trichopoulou A., Soukara S., Vasilopoulou E. (2007). Traditional foods: a science and society perspective. Trends in Food Science \& Technology, 18, 420-427.

15. Vasilopoulou E., Trichopoulou A. (2013). Nutritional claims: a potentially important tool for the endorsement of Greek Mediterranean traditional foods. Mediterranean Journal of Nutrition and Metabolism, 6, 105-111.

16. Vessby B., Unsitupa M., Hermansen K., Riccardi G., Rivellese A.A., Tapsell L.C. (2001). Substituting dietary saturated for monounsaturated fat impairs insulin sensitivity in healthy men and women: the KANWU Study. Diabetologia, 44, 312-9.

17. Wahrburg U. (2004). What are the health effects of fat? European Journal of Nutrition, $43, \mathrm{I} / 6-\mathrm{I} / 11$

\section{ТРАДИЦИОНАЛНА ХРАНА У СРБИЈИ: ИЗВОРИ, РЕЦЕПТИ И ПРОФИЛИ МАСНИХ КИСЕЛИНА}

Тамара Б. Поповић, Александра Ч. Арсић, Јасмина Д. Дебељак Мартачић, Гордана П. Петровић Oggiano, Мирјана А. Гуриновић, Весна М. Вучић, Марија Д. Глибетић

Универзитет у Београду, Институт за медицинска истраживања, Др Суботића бр. 4, 11129 Београд, Србија

Сажетак: Традиционална храна има важну улогу у различитим културама и регионима, док начини њене припреме представљају део обичаја земље или региона.

У овом раду су представљени рецепти и масно-киселински профили неких од уобичајено конзумираних традиционалних јела у Србији. Традиционални српски млечни производи, сир и кајмак, садржавали су $70 \%$ засићених масних киселина, углавном палмитинске киселине. Често конзумирано јело пребранац, садржавало је $38.67 \%$ палмитинске и $35.58 \%$ олеинске киселине, док је је садржај линолне киселине био 17.34\%. Ајвар, често коришћен као салата, има висок садржај линолне киселине (49.12\%). Детектовани су веома мали садржаји транс масних киселина у свим испитиваним узорцима хране. Глобализација и интернационализација тржишта хране доприносе ризику нестајања традиционалне хране, те су подаци о њој важни за очување културног наслеђа.

Кључне речи: традиционална храна, профил масних киселина

Received: 18 February 2014 